\title{
From the First Spectral Analysis of Blood Pressure Variability in the World to the Present Time: Contribution of the Department of Physiology of the Faculty of Medicine, Masaryk University, Brno
}

\author{
Dedicated to Professor MUDr. Nataša Honziková, CSc., on the occasion of her $65^{\text {th }}$ birthday.
}

\section{Z. NOVÁKOVÁ 1}

${ }^{1}$ Department of Physiology, Faculty of Medicine, Masaryk University, Brno, Czech Republic

Received February 22, 2013

Accepted April 12, 2013

On-line April 16, 2013

\section{Summary}

The review shows the significance of blood pressure regulation studies conducted during several decades at the Department of Physiology, Faculty of Medicine, Masaryk University, Brno. Continuous non-invasive blood pressure measurement was first introduced and patented here and, with the obtained data, the first spectral analysis of blood pressure was performed. This method was used in many different physiological studies on the relationship of blood pressure regulation to circulatory parameters, breathing, and baroreflex sensitivity. The article deals with studies on risk stratification of sudden cardiac death according to decreased baroreflex sensitivity, 24-hour heart rate variability, the amount of extrasystoles and late potentials. Importance of the new method of determination of one summation risk index is described here. A summary of the new conception of the relationship between low baroreflex sensitivity and hypertension is presented. Here, not only pathological changes of the vessel wall but also increased sympathetic activity and genetic predisposition play a role. Importance of studies conducted in young adults is highlighted, as inherited BRS decrease contributes to earlier blood pressure increase in the young. This research is highly topical, since prevention of hypertension in childhood is possible. Recent studies are dedicated to blood pressure regulation in young diabetics.

\section{Key words}

Finger arterial blood pressure - Blood pressure variability • Baroreflex sensitivity • Sudden cardiac death • Hypertension • Area under receiving operating curve

\section{Corresponding author}

Z. Nováková, Department of Physiology, Faculty of Medicine, Masaryk University, Kamenice 5, CZ-625 00 Brno, Czech Republic. E-mail: znovak@med.muni.cz

It is a great honour for me to review, on the occasion of the $65^{\text {th }}$ birthday of Professor MUDr. Nataša Honzíková, CSc., the significance of studies in blood pressure regulation conducted during several decades at the Department of Physiology of the Faculty of Medicine, Masaryk University. Born in Brno on 11 August 1948, Professor Nataša Honzíková has belonged to distinguished Czech physiologists and her life has been entirely devoted to studies of cardiovascular regulation. She started to work in the laboratory of Professor MUDr. Jan Peňáz, CSc., in co-operation with Professor MUDr. Bohumil Fišer, CSc., in the seventies of the last century and she conducted this research during the last decades.

This research team laid the foundations of later internationally used methods of evaluation of short-term blood pressure variability using spectral analysis, and of additional methods derived from spectral analysis of short-term variations of circulatory parameters involved in blood pressure regulation. 
History of the introduction of spectral analysis of blood pressure variability recorded continually and non-invasively from finger arteries

We have to return to the year 1969, when Jan Penáz patented the non-invasive continuous method of blood pressure measurement from finger arteries and constructed a reliable device called plethysmomanometer (Peňáz 1969). Shortly afterwards, during his stay in the Netherlands, he applied spectral analysis to the quantifications of short-term variability of heart rate and blood flow measured beat-to-beat by plethysmography (Peňáz et al. 1968). Such an approach had not been used in the physiology of circulation. At that time Nataša Honzíková started to work at the Department of Physiology as a student and, in 1973, as an assistant. Under the guidance of Peňáz, she started to work on the implementation of spectral analysis in blood pressure variability recorded continuously by Peňáz's plethysmomanometer.

To understand the significance of the introduction of spectral analysis of waves in blood pressure in Brno, it is useful to describe more closely the conditions under which these first studies in the world on spectral analysis of blood pressure were created. It was before four decades in Czechoslovakia, where computer technology was not commonly available. The present generation of young novices of science can hardly imagine work under such conditions. The methodical approach, programming and computation were at that time realised by Professor Ing. Jan Honzík, CSc., who was a young assistant at the Department of Computers of the Faculty of Electrical Engineering of the Brno University of Technology. Already the first analysis was conceived with the idea to get information about controlling linkage between rhythmical variations in blood pressure, heart rate, finger blood flow, and respiration. It was necessary to manually read tens of thousands of values and to transfer them onto punched cards. The results of this exacting study were presented in 1975 (Honzíková et al. 1975), full-extent papers were published in 1978 (Fišer et al. 1978, Peňáz et al. 1978). It is noteworthy how much information valid till now is contained in these pioneering studies - starting from the relationships between variability in more parameters (systolic, diastolic, and pulse pressures, cardiac intervals, finger blood flow and respiration), to coherence and phase shift between these signals, and individual differences and repeatability after 20 minutes as well.
These key studies remained for a longer time without any response, because no laboratory had at its disposal a device for a non-invasive continuous blood pressure recording. It was Professor Karel Wesseling in the Netherlands who recognised the significance of this methodology. He contributed to a further technical development of this method. Let me mention just some examples from a whole group of publications from this period (Wesseling et al. 1982, Molhoek et al. 1984). This development led to the commerce device Finapres (Ohmeda, USA) which, after introduction to the market, opened a boom in studies based on spectral analysis of blood pressure variability.

In the 1980s, Nataša Honzíková pursued the analysis of the relationship between variability in circulation on the one hand and variation of depth and rate of respiration on the other. She was the first to draw attention to the fact that the influence of respiration on circulation is manifested not only in the typical respiratory frequency, in the so-called high-frequency spectral range (HF), but also in the so-called lowfrequency range (LF). Although she, for political reasons, did not find doors opened for publication in Czechoslovakia in the 1980s, she was repeatedly invited abroad as an invited speaker, and she was successful in presenting there studies on the interpretation of differences in the power spectra of blood pressure, heart rate and respiration in man (Honzíková et al. 1987), and on the role of changes in depth and rate of respiration played in changes of respiratory rhythms during mental load (Honzíková et al. 1988). The study on individual characteristics of circulatory and respiratory spectra at one year's distance was also of high priority at that time (Honzíková et al. 1990).

During this period studies were published in Brno on the thermoregulatory effects on circulatory and respiratory variability (Honzíková et al. 1984), on the effect of regular and random respiration on circulatory spectra (Honzíková and Peňáz 1985), a study was published on the circulatory spectra during static workload (Honzíková et al. 1986), and the most important of them was a monograph which was written in the eighties, but published later after political changes in our country (Honzíková 1990). This monograph summarised her own previous studies on circulatory spectra in the context of the current state of knowledge, but it also contained a fully new procedure of evaluation of the fluctuation of peripheral resistance based on changes of the rate of blood pressure decrease during the diastole. This monograph was one of very rare books 
issued at that time in the world. They were mostly published in the Netherlands, where Finapres was developed (de Boer 1985).

The conference "Volume-clamp recording of blood pressure in man", which was organised as part of the Regional Meeting of the International Union of Physiological Societies in honour of Peňáz in 1991, was a considerable contribution to international access to methods based on continual blood pressure recording in finger arteries. It was followed by the publication of a set of 30 papers by authors all over the world in several issues of the journal Homeostasis edited by $\mathrm{N}$. Honzíková, T. H. Schmidt from Hannover, and K. H. Wesseling from Amsterdam, where Nataša Honzíková also contributed by some studies (Honzíková et al. 1995a,b, Weise et al. 1995, Honzíková et al. 1996).

\section{Determination of baroreflex sensitivity by spectral method}

Blood pressure is controlled by many nervous and humoral mechanisms - systemic and local. As regards nervous regulation of blood pressure, baroreflex is the most important mechanism. It has several branches, but heart rate response to blood pressure variations is studied mostly quantitatively. Changes of cardiac intervals caused by variations in blood pressure via stimulation of baroreceptors are usually quantified as index baroreflex sensitivity (BRS) that corresponds to a change of the cardiac interval due to a change of blood pressure $(\mathrm{ms} / \mathrm{mm} \mathrm{Hg})$. This mechanism operates beat by beat and is evaluated from continuous recordings of blood pressure and cardiac intervals. There is a variety of methods of baroreflex sensitivity determination, as for instance evaluation of beat-to-beat changes of blood pressure and cardiac intervals after the administration of a vasoactive drug, which opened such studies (Smyth et al. 1969), and a whole array of further methods which were introduced during the following decades: evaluation of upward- and downward-sloping groups of pulses in spontaneous recordings, various indices based on crossspectral analysis, alpha index, wavelet approach, and LP analysis. A number of studies have compared BRS results as obtained by different methods (Krticka et al. 2000, Persson et al. 2001, Krticka and Honzikova 2001, Lipman et al. 2003, Laude et al. 2004).

The introduction of determination of baroreflex sensitivity by the spectral method in the 1980s (Robe et al. 1987) represented a methodological step forward in the exploitation of spectral analysis of the blood-pressure and heart-rate variabilities. Nataša Honzíková in cooperation with Bohumil Fišer and Jan Honzík were among the first to apply the cross-spectral method for BRS determination at a frequency of $0.1 \mathrm{~Hz}$ during orthostasis, static and emotional load, and to compare it with other methods of BRS determination (Honzíková and Fišer 1991, Honzíková et al. 1992a,b). Nataša Honzíková's participation in one of the first comparative studies of methods of BRS determination was a natural consequence of her international appreciation (Persson et al. 2001).

In a variety of methodological studies conducted by our group extended by younger co-workers and in cooperation with Professor Swenne and his colleagues in the Netherlands we have shown that there is a difference between BRS values determined at a respiratory frequency and a frequency of $0.1 \mathrm{~Hz}$ (Fredericks et al. 1997, 2000, Bothová et al. 2010, Swenne 2013). These studies have also shown that the value of BRS determined at a breathing frequency overestimates on average the real BRS in comparison with that determined at a frequency of $0.1 \mathrm{~Hz}$, even though an opposite relationship between both values may be present in some subjects. This effect is dependent on a different mechanism of the development of variation in blood pressure and cardiac intervals, which is not only a result of baroreflex. With respect to the fact that respiratory sinus arrhythmia is also affected by additive reflexes, for instance from pulmonary mechanoreceptors (Hainsworth 1974), or by a central irradiation of activity from the respiratory centre (Eckberg 2003, Eckberg and Karemaker 2009), we examine BRS at a frequency of $0.1 \mathrm{~Hz}$ using metronome-controlled breathing at a frequency which is substantially higher than $0.1 \mathrm{~Hz}$ and is not a multiple of $0.1 \mathrm{~Hz}$ to eliminate the respiratory baroreflex-non-related influence and a resonance effect on heart rate fluctuations. It is important that BRS represents an individually characteristic feature, even though it is spontaneously fluctuating to some extent (Jíra et al. 2006, Dietrich et al. 2010). From the point of view of diagnostic application of this method it is important that spontaneous fluctuation of BRS is low in persons with its low value, which is associated with essential hypertension and is a risk factor in many cardiovascular diseases (Jíra et al. 2006). It is also necessary, during a diagnostic evaluation of the BRS changes, to take into account the fact that the value of the BRS index in $\mathrm{ms} / \mathrm{mm} \mathrm{Hg}$ is influenced by mean duration of the cardiac 
interval, which may mask some fine changes of baroreflex sensitivity, for instance its decrease at the age between 10 and 19 years when vagal tone and mean heart rate develop. In such cases a baroreflex sensitivity decrease is proved by the BRSf index in $\mathrm{mHz} / \mathrm{mm} \mathrm{Hg}$, which is less dependent on the mean cardiac interval (Zavodna et al. 2006). On the other hand, a change of the mean cardiac interval may cause a change of the BRS index which need not be found in the BRSf index (not yet published results of a study of early changes of baroreflex sensitivity in adolescents with type 1 diabetes mellitus). Naturally, both indices, BRS and BRSf, provide the same information at high pathological decrease of baroreflex sensitivity (Honzíková et al. 2006a).

\section{Prediction of the risk of sudden cardiac death}

As early as some 20 years ago, Professor Honzíková posed herself a question on the possible significance of spectral analysis of blood pressure variability for practical medicine. In the 1990s she started, in co-operation with Professor Bohumil Fišer and with the First Department of Cardiology headed by Professor Borrivoj Semrád, to test the significance of the BRS decrease determined by spectral analysis of resting recordings of blood pressure in finger arteries in patients after myocardial infarction (Honzíková et al. 1993, 1994, 1995c). A decreased BRS as a marker of the risk of sudden cardiac death was evaluated at that time using intravenous application of the vasoconstrictor phenylephrine first in animals (Schwartz et al. 1988) and later in patients (Bigger et al. 1989, La Rovere et al. 1998). An explanation of the mechanism by which high BRS prevents sudden cardiac death is as follows: Quick prolongation of the cardiac interval following a sudden blood pressure elevation decreases cardiac workload. This is important in an ischaemic myocardium, especially after myocardial infarction, and therefore high BRS decreases the risk of sudden cardiac death. The importance of the approach to BRS determination based on spectral analysis of a non-invasive resting recording of blood pressure is in a reduced load of the patients after myocardial infarction by such an examination. It was shown that a critical risk value of BRS determined by the spectral method is comparable with that obtained by the phenylephrine method (Honzikova et al. 2000a) and represents an important risk factor (Honzíková et al. 2000b). The above-mentioned study (Honzíková et al. 2000b) was broadly conceived and showed that the simultaneous evaluation of indices characterising changes in autonomic control of heart rate (BRS and SDANN index derived from 24 hour ECG monitoring), of a lowered pumping function of the heart (ejection fraction), of an increased excitability of the myocardium (the number of extrasystoles per 24 hours determined during ECG monitoring), and of changes in activation of the myocardium (presence of late potentials) disclosed a different and mutually amplifying effect of individual factors on the risk of sudden cardiac death. These studies were quickly accepted and included in an American study on the decision to implant a cardioverter defibrillator after myocardial infarction (Bailey et al. 2007). Nevertheless, tens of further studies on prediction of the risk of sudden cardiac death have shown that no single index exhibits a satisfactory sensitivity and specificity in a therapeutic decision in risky patients. On the other hand, a multiple regression analysis comprising more risk indices brought evidence of the increased risk when more risky factors were present. However, such statistical analysis cannot give a clear answer whether a particular patient should be included in a highly risky group. Nowadays, the process of decision is resolved in several steps. Several years ago, Professor Honzíková started to co-operate with Petr Honzík on the development of a mathematical method of the determination of one summation risk index of risky patients which included a group of risk factors. This index includes: (1) significance (weight) of the individual risk factors; (2) fuzzification of the critical value, that means blurring of the critical risky value of individual indices, because the critical values were determined statistically and did not take into account that the risk rate of a patient is also influenced by values of indices near to critical values (Honzik 2005, Honzík et al. 2002, 2003, 2009). Thus, they created a general instrument which we applied also in other areas of research, in a study of early states of hypertension in adolescents or in cardiomyopathy (Krontorádová et al. 2008, Honzík et al. 2010). We suppose that this concept will also be profitable in other areas of clinical research.

\section{Low baroreflex sensitivity as a symptom of essential hypertension and as a factor conditioning its development}

Myocardial infarction is a frequent complication of essential hypertension. This is one of the reasons why studies of BRS in hypertensive patients are important 
with respect to prediction of a potential risk of these patients in case of myocardial infarction.

Low BRS (under $5 \mathrm{~ms} / \mathrm{mm} \mathrm{Hg}$ ) was repeatedly observed in patients with hypertension several years ago. Naturally, a question arose what is the cause of a BRS decrease in hypertensive patients. It was proved that low BRS in hypertensive patients was associated with a thickening of the carotid intima-media in the carotid bulb, a region with a high baroreceptor density and with the presence of atherosclerosis (Zanchetti et al. 1998, Gianaros et al. 2002). In our studies we have also confirmed a linkage of remodelling and thickening of the carotid intima-media of the carotid wall with high blood pressure and low baroreflex sensitivity (Lábrová et al. 2005, Honzikova et al. 2006b).

There are also several additive factors, such as sympathetic activation in obesity due to the release of leptin, which also secondarily suppresses BRS. It has been shown that obesity is associated with a higher risk of high blood pressure in both adults and children (Lurbe et al. 1998, Rahmouni et al. 2005, Honzíková et al. 2006a, Honzíková and Fišer 2009, Lazarova et al. 2009). All these studies lead to the interpretation that the decrease of BRS in hypertonic patients should be understood as a symptom dependent on several factors (increased arterial stiffness, increased sympathetic activity and obesity). There are some epidemiological proofs that the growing obesity in young population increases the prevalence of hypertension in adolescents and young adults (Freedman et al. 1999, Sorof 2002).

Professor Honzíková with Dr. Z. Nováková initiated several studies in children and adolescents (Nováková et al. 1997, 1998, Honzíková et al. 2000c) with the aim to evaluate whether an inborn disposition to a low BRS could also influence, as one of the primary factors, the risk of early blood pressure elevation. It was in a period when there was hardly any interest in studying baroreflex in children in the world, because hypertension and its complications are diseases of adult population. That is to say that we made an interesting observation in our physiological study showing that about $5 \%$ of a group of 400 healthy children and adolescents (aged 10-19 years) had their BRS as low $(3.9 \mathrm{~ms} / \mathrm{mm} \mathrm{Hg})$ as could well be supposed to be a symptom of hypertension and to suggest a disposition of the patient to complications such as myocardial infarction (Zavodna et al. 2006).

This analysis evoked an interest in studying inborn dispositions to low BRS. Previously, basic information had been obtained from studies on twins. Significant correlations were found for BRS in monozygotic, but not in dizygotic twin pairs (Tank et al. 2001). It is not surprising that nowadays genetic studies are performed; we also started such an analysis (Jíra et al. 2010). Nevertheless, a serious understanding of the genetic conditioning of BRS will be very complicated, because the genetic contribution to a BRS value could involve different components of the baroreceptor reflex arc, including baroreceptors, reflex afferent and efferent pathways, central neuronal transmission, and the sinoatrial node. In all of these parts there act numerous ligands, receptors, channels, etc. Summarisations of the current knowledge of the genetics of BRS were published last year (Honzikova and Zavodna 2012, Jordan and Biaggioni 2012).

It seemed therefore useful to examine BRS in a broader young population and to find some indirect proof of the influence of a primarily low BRS on blood pressure. We have found a decreased BRS and BRSf in children, adolescents and young adults (11-21 years) with white-coat hypertension and early hypertension (Honzíková et al. 2006a). The stepwise blood pressure elevation in these groups was associated, besides a stepwise decrease of BRS/BRSf, also with a stepwise increase of the body mass index. Such a finding in hypertonics may correspond with a possible starting atherosclerotic process and remodelling of the arteries. A quite different situation is in those with white-coat hypertension. These young subjects have a mostly physiological blood pressure all over the day and there is no reason for a remodelling of the arterial wall. However, their hyperreactivity of blood pressure changes may be influenced by primarily low BRS.

A direct evidence that low baroreflex sensitivity is a partially independent risk factor for the development of essential hypertension was provided by our study Krontorádová et al. (2008). Although young hypertonic subjects of this study had a significantly lower BRS and a significantly higher BMI than the controls, there was no correlation between BMI and BRS either in the group of hypertonics or in the controls. We applied our original method (Honzík et al. 2002, 2010) in a detailed evaluation of the effect of both factors, BMI and BRS, on blood pressure elevation. The predicting power of BMI, BRS, and an index determined on the basis of combination of values of BMI and BRS was further evaluated. The optimal critical values for the diagnostics of hypertension were determined by the receiver-operating curves (ROC) 
for all three indices. The sensitivity, specificity, and the area under the ROC were increased in predicting hypertension for a summation index based on a combination of both factors, BRS and BMI. This documented that low BRS could be a partially independent risk factor for the development of essential hypertension.

Professor Honzíková summarised, in a chapter in a monograph (Honzikova and Zavodna 2012), this new insight into the role of low baroreflex sensitivity in essential hypertension - as a generally accepted symptom linked with arterial stiffness, sympathetic activation and obesity on the one hand and as a possible additive factor conditioning its development on the other.

\section{Application of spectral analysis of blood pressure variability in diagnostics in children and adolescents}

Last but not least, Professor Honzíková, in cooperation with Professor Hrstková and co-workers, also took part in clinical studies of blood pressure regulation in childhood. The aim of these studies was to find some markers of early changes of control in circulation in special groups of patients with increased risk of cardiovascular complications in future. This was especially a prospective study in children and adolescents after antitumour therapy by drugs with possible negative side effects on the cardiovascular system. Even though these young people are fully healthy, we have found in some of them decreased BRS and a tendency to a slowed development of blood pressure compared with its physiological increase during adolescence, and also a large drop of blood pressure in the night hours (Nováková et al. 2007, 2010).

Another risk group from the point of view of functioning of the cardiovascular system in later decades of life is represented by children with type 1 diabetes mellitus. A study performed in co-operation with the team of Assoc. Prof. M. Javorka (Martin, Slovakia) disclosed their tendency to an early BRS decrease (Javorka et al. 2011) and a shift of the spectral peak frequency (cross-spectrum of variations in blood pressure and cardiac intervals) in the range around $0.1 \mathrm{~Hz}$ to lower frequencies (Honzíková et al. 2012).

\section{Conclusion}

In conclusion I would like to summarise the value of the lifelong studies of Professor Honzíková for the understanding of the physiology of circulation control. In the 1970s, Professor Honzíková participated in the introduction of spectral analysis of blood pressure variability recorded by the non-invasive continuous method from finger arteries into quantification of the control mechanisms of blood pressure, which has nowadays been generally used in thousands of studies all over the world, and also in the development of a method for the determination of dynamic compliance of finger arteries (Peňáz et al. 1997), which awaits its further applications. Her indubitable contribution to the evaluation and understanding of the physiology of beatby-beat blood pressure variability, its ontogenetic development and individual characteristics should be acknowledged. From the point of view of clinical medicine the studies of the risk of sudden cardiac death after myocardial infarction are of the utmost importance. The complex of studies of baroreflex sensitivity in children and adolescents, which brought evidence that inborn low baroreflex sensitivity may be linked with the early blood pressure elevation in youth, may be of importance in future. This area of research is highly topical with respect to preventative medicine.

It is only natural that the majority of the studies was conducted in co-operation with clinicians. Professor Honzíková encouraged such co-operation, also with a substantial share of doctoral students. Some of her previous students continue doing research at our Department of Physiology, others continue in medical practice and research in the Faculty Hospital in Brno. It is an honour for me that I could grow under the leadership of Professor Honzíková and take part in many of these studies.

\section{Conflict of Interest}

There is no conflict of interest.

\section{Acknowledgements}

Supported by Specific project: MUNI/A/0951/2012.

\section{References}

BAILEY JJ, HODGES M, CHURCH TR: Decision to implant a cardioverter defibrillator after myocardial infarction: The role of ejection fraction v. other risk factor markers. Med Decis Making 27: 151-160, 2007. 
BIGGER JT, LA ROVERE MT, STEINMAN RC, FLEISS JL, ROTTMAN JN, ROLNITZKY LM, SCHWARTZ PJ: Comparison of baroreflex sensitivity and heart period variability after myocardial infarction. $J$ Am Coll Cardio 14: 1511-1518, 1989.

BOTHOVÁ P, HONZÍKOVÁ N, FIŠER B, ZÁVODNÁ E, NOVÁKOVÁ Z, KALINA DR, HONZÍKOVÁ K, LÁBROVÁ R: Comparison of baroreflex sensitivity determined by cross-spectral analysis at respiratory and 0.1 Hz frequencies. Physiol Res 59: S103-S111, 2010.

DE BOER RW: Beat-to-beat blood-pressure fluctuations and heart-rate variability in man: physiological relationships, analysis techniques and simple model. Drukkerij Elinkwijk BV, Utrecht, 1985, p. 191.

DIETRICH A, ROSMALEN JGM, ALTHAUS M, VAN ROON AM, MULDER LJM, MINDERAA RB, OLDEHINKEL AJ, RIESE H: Reproducibility of heart rate variability and baroreflex sensitivity measurements in children. Biol Psychol 85: 71-78, 2010.

ECKBERG DL: The human respiratory gate. J Physiol 548: 339-352, 2003.

ECKBERG DL, KAREMAKER JM: Point:Counterpoint: Respiratory sinus arrhythmia is due to a central mechanism vs. respiratory sinus arrhythmia is due to the baroreflex mechanism. J Appl Physiol 106: 1740-1744, 2009.

FIŠER B, HONZÍKOVÁ N, PEŇÁZ J: Power spectra of spontaneous variations of indirectly recorded blood pressure, heart rate and acral blood flow. Automedica 2: 143-147, 1978.

FREEDMAN DS, DIETZ WH, SRINIVASAN SR, BERENSON GS: The relation of overweight to cardiovascular risk factors among children and adolescents: The Bogalusa Heart Study. Pediatrics 103: 1175-1182, 1999.

FREDERIKS J, SWENNE CA, TENVOORDE BJ, HONZIKOVA N, LEVERT JV, MAAN AC, SCHALIJ MJ, BRUSCHKE AVG: Non-baroreflex mediated heart rate variability causes overestimation of baroreflex sensitivity. Comput Cardiol 24: 199-202, 1997.

FREDERIKS J, SWENNE CA, TENVOORDE BJ, HONZIKOVA N, LEVERT JV, MAAN AC, SCHALIJ MJ, BRUSCHKE AVG: The importance of high-frequency paced breathing in spectral baroreflex sensitivity assessment. J Hypertens 18: 1635-1644, 2000.

GIANAROS PJ, JENNINGS JR, OLAFSSON GB, STESTOE A, SUTTON-TYRELL K, MULDOON MF, MANUCK SB: Greater intima-media thickness in the carotid bulb is associated with reduced baroreflex sensitivity. Am J Hypertens 15: 486-491, 2002.

HAINSWORTH R: Circulatory response from lung inflation in anesthetized dogs. Am J Physiol 226: 247-255, 1974.

HONZÍK P, HRABEC J, LÁBROVÁ R, SEMRÁD B, HONZÍKOVÁ N: Risk stratification of patients after myocardial infarction by the fuzzy and weighted methods. In: Analysis of Biomedical Signals and Images. 16th International Eurasip Conference Biosignal 2002. J JAN, J KOZUMPLÍK, I PROVAZNÍK (eds), Vutium Press, Brno, University of Technology. Proceedings, 2002, pp 463-465.

HONZÍK P, HRABEC J, LÁBROVÁ R, SEMRÁD B, HONZÍKOVÁ N: Fuzzification, weight and summation of risk factors in a patient improves the prediction of risk for cardiac death. Scripta Medica 76: 141-148, 2003.

HONZIK P: Area under the ROC curve by Bubble-Sort approach (BSA). In: Proceedings of the 7th WSEAS International Conference on Automatic Control, Modeling and Simulation. V SROVNAL, N MASTORAKIS (eds), WSEAS Athens, Greece, 2005, pp 494-499.

HONZIK P, KUCERA P, HYNCICA O, JIRSIK V: Area under the receiver operating characteristic as a sorting problem. In: 15th International Conference on Soft Computing. M RADEK (ed), Brno Univ Technology VUT Press, Brno, 2009, pp 277-282.

HONZÍK P, KŘIVAN L, LOKAJ P, LÁBROVÁ R, NOVÁKOVÁ Z, FIŠER B, HONZÍKOVÁ N: Logit and fuzzy models analysis: estimation of risk in cardiac patients. Physiol Res 59: S89-S96, 2010.

HONZÍKOVÁ N: Spectral analysis of circulatory rhythms. Masaryk University, Brno, 1990, 125 pp.

HONZÍKOVÁ N, FIŠER B: Spectral analysis of circulatory rhythms and baroreflex sensitivity in man. In: Rhythms in Physiological Systems. H HAKEN, HP KOEPCHEN (eds), Springer, Berlin, 1991, pp 97-102.

HONZÍKOVÁ N, FIŠER B: Baroreflex sensitivity and essential hypertension in adolescents. Physiol Res 58: 605-612, 2009.

HONZÍKOVÁ N, PEŇÁZ J: Influence of modified respiratory rhythm on fluctuations of circulatory parameters. Scripta Medica 58: 323-336, 1985. 
HONZIKOVA N, ZAVODNA E: Is low baroreflex sensitivity only a consequence of essential hypertension or also a factor conditioning its development? In: Genetics and Pathophysiology of Essential Hypertension. M KHULLAR (ed), InTech, 2012, pp 67-88.

HONZÍKOVÁ N, PEŇÁZ J, FIŠER B: Spectral analysis of spontaneous fluctuations of some cardiovascular variables. Physiol Bohemoslov 24: 441-442, 1975.

HONZÍKOVÁ N, PEŇÁZ J, FIALOVÁ Z, POSTRÁNECKÁ V: The influence of cold and heat on the variability of respiratory and circulatory parameters. Scripta Medica 57: 265-270, 1984.

HONZÍKOVÁ N, PEŇÁZ J, FIŠER B: Spectral analysis of circulatory parameters during static exercise in man. Scripta Medica 59: 197-201, 1986.

HONZÍKOVÁ N, PEŇÁZ J, FIŠER B: Interpretation of differences in power spectra of blood pressure, heart rate and respiration in man. In: Chronobiology and Chronomedicine. G HILDEBRANDT, R MOOG, F RASCHKE (eds), Peter Lang, Frankfurt am Main, 1987, pp 172-176.

HONZÍKOVÁ N, PEŇÁZ J, FIŠER B: Power spectra of blood pressure and heart rate fluctuations during mental load. J Interdiscipl Cycle Res 19: 75-79, 1988.

HONZÍKOVÁ N, PEŇÁZ J, FIŠER B: Individual features of circulatory power spectra in man. Eur J Appl Physiol Occup Physiol 59: 430-434, 1990.

HONZÍKOVÁ N, FIŠER B, HONZÍK J: Noninvasive determination of baroreflex sensitivity in man by means of spectral analysis. Physiol Res 41: 31-37, 1992a.

HONZÍKOVÁ N, FIŠER B, KUKLETA M, HONZÍK J, PEŇÁZ J: Baroreflex sensitivity assessed by spectral analysis. $R$ Medizin 41: 67-70, 1992b.

HONZÍKOVÁ N, FIŠER B, SEMRÁD B: Noninvasive determination of baroreflex sensitivity in patients with myocardial infarction. Physiol Res 42: 12P, 1993.

HONZÍKOVÁ N, SEMRÁD B, FIŠER B, LÁBROVÁ R: Heart rate variability and baroreflex sensitivity in postinfarction patients. Eur JCE 4: 181, 1994.

HONZÍKOVÁ N, FIŠER B, PEŇÁZ J, HONZÍK J: The relationship between spontaneous fluctuations in diastolic pressure and in the rate of blood pressure decrease during diastole. Homeostasis 36: 160-164, 1995a.

HONZÍKOVÁ N, PEŇÁZ J, FIŠER B, HONZÍK J: The relationship between spontaneous fluctuations in circulation and depth and rate of respiration. Homeostasis 36: 165-169, $1995 \mathrm{~b}$.

HONZÍKOVÁ N, SEMRÁD B, FIŠER B: Baroreflex sensitivity and heart rate variability in patients after myocardial infarction: effect of thrombolytic therapy. In: Measurement of Heart Rate and Blood Pressure Variability in Man. AJ MAN In T' VELD, GA VAN MONTFRANS, GJ LANGEWOUTERS, KI LIE, G MANCIA (eds), Van Zuiden Communications BV, Amsterdam, 1995c, pp 113-117.

HONZÍKOVÁ N, RYBKOVÁ I, HONZÍK JM: Baroreflex sensitivity, heart rate and blood pressure during mental load and emotional activation. Homeostasis 37: 72-76, 1996.

HONZIKOVA N, FISER B, SEMRAD B: Critical value of baroreflex sensitivity determined by spectral analysis in risk stratification after myocardial infarction. PACE 23: 1965-1967, 2000a.

HONZÍKOVÁ N, SEMRÁD B, FIŠER B, LÁBROVÁ R: Baroreflex sensitivity determined by spectral method and heart rate variability, and two-years mortality in patients after myocardial infarction. Physiol Res 49: 643-650, 2000 b.

HONZÍKOVÁ N, FIŠER B, HRSTKOVÁ H, NOVÁKOVÁ Z, VÁCLAVKOVÁ P: Twenty-four hour blood pressure profile and baroreflex sensitivity in children and adolescents with essential hypertension. J Hypertens 18: P47, 2000c.

HONZÍKOVÁ N, NOVÁKOVÁ Z, ZÁVODNÁ E, PADĚROVÁ J, LOKAJ P, FIŠER B, BALCÁRKOVÁ P, HRSTKOVÁ H: Baroreflex sensitivity in children, adolescents, and young adults with essential and white-coat hypertension. Klin Paediatr 218: 237-242, 2006a.

HONZIKOVA N, LABROVA R, FISER B, MADEROVA E, NOVAKOVA Z, ZAVODNA E, SEMRAD B: Influence of age, body mass index, and blood pressure on the carotid intima-media thickness in normotensive and hypertensive patients. Biomed Tech 51: 159-162, $2006 \mathrm{~b}$. 
HONZÍKOVÁ N, KRTIČKA A, ZÁVODNÁ E, JAVORKA M, TONHAJZEROVÁ I, JAVORKA K: Spectral peak frequency in low-frequency band in cross spectra of blood pressure and heart rate fluctuations in young type 1 diabetic patients. Physiol Res 61: 347-354, 2012.

JAVORKA M, LAZAROVA Z, TONHAJZEROVA I, TURIANIKOVA Z, HONZIKOVA N, FISER B, JAVORKA K, BAUMERT M: Baroreflex analysis in diabetes mellitus: linear and nonlinear approaches. Med Biol Eng Comput 49: 279-288, 2011.

JÍRA M, ZÁVODNÁ E, HONZÍKOVÁ N, NOVÁKOVÁ Z, FIŠER B: Baroreflex sensitivity as an individual characteristic feature. Phys Res 53: 349-351, 2006.

JÍRA M, ZÁVODNÁ E, HONZÍKOVÁ N, NOVÁKOVÁ Z, VAŠKU゚ A, IZAKOVIČOVÁ HOLLÁ L, FIŠER B: Association of AC polymorphism in AT1 receptor gene with baroreflex sensitivity. Physiol Res 59: 517-528, 2010.

JORDAN J, BIAGGIONI I: Genetic influences on human baroreflex regulation. Auton Neurosci 172: 23-25, 2012.

KRONTORÁDOVÁ K, HONZÍKOVÁ N, FIŠER B, NOVÁKOVÁ Z, ZÁVODNÁ E, HRSTKOVÁ H, HONZÍK P: Overweight and decreased baroreflex sensitivity as independent risk factors for hypertension in children, adolescents, and young adults. Physiol Res 57: 385-391, 2008.

KRTICKA A, HONZIKOVA N, FISER B, NOVAKOVA Z: Four signal processing techniques for continuous baroreflex determination. In: Proceedings of Annual International Conference of the IEEE Engineering in Medicine and Biology Society. JD ENDERLE (ed), IEEE, New York, 2000, pp 3168-3171.

KRTICKA A, HONZIKOVA N: Wavelet transform and continuous baroreflex determination. In: MEDICON 2001: Proc IFMBE. R MAGJAREVIC, S TONKOVIC, V BILAS, I LACKOVIC (eds), Univ Zagreb, Pula, 2001, pp 356-359.

LIPMAN RD, SALISBURY JK, TAYLOR JA: Spontaneous indices are inconsistent with arterial baroreflex gain. Hypertension 42: 481-487, 2003.

LA ROVERE MT, BIGGER JT, MARCUS FI, MORTARA A, SCHWARTZ PJ: Baroreflex sensitivity and heart-rate variability in prediction of total cardiac mortality after myocardial infarction. ATRAMI (Autonomic tone and reflexes after myocardial infarction) investigators. Lancet 351: 478-484, 1998.

LÁBROVÁ R, HONZÍKOVÁ N, MADĚROVÁ E, VYSOČANOVÁ P, NOVÁKOVÁ Z, ZÁVODNÁ E, FIŠER B, SEMRÁD B: Age-dependent relationship between the carotid intima-media thickness, baroreflex sensitivity, and the inter-beat interval in normotensive and hypertensive subjects. Physiol Res 54: 593-600, 2005.

LAUDE D, ELGHOZI JL, GIRARD A, BELLARD E, BOUHADDI M, CASTIGLIONI P, CERUTTI C, CIVIDJIAN A, DIRIENZO M, FORTRAT JO, JANSSEN B, KAREMAKER JM, LEFTHERIOTIS G, PARATI G, PERSSON PB, PORTA A, QUINTIN L, REGNARD J, RUDIGER H, STAUSS HM: Comparison of various techniques used to estimate spontaneous baroreflex sensitivity (the EuroBaVar study). Am J Physiol-Reg I 286: R226-R231, 2004.

LAZAROVA Z, TONHAJZEROVA I, TRUNKVALTEROVA Z, BROZMANOVA A, HONZIKOVA N, JAVORKA $\mathrm{K}$, BAUMERT M, JAVORKA M: Baroreflex sensitivity is reduced in obese normotensive children and adolescents. Can J Physiol Pharmacol 87: 565-571, 2009.

LURBE E, ALVAREZ V, LIAO Y, TACONS J, COOPER R, CREMADES B, TORRO I, REDON J: The impact of obesity and body fat distribution on ambulatory blood pressure in children and adolescents. Am J Hypertens 11: 418-424, 1998.

MOLHOEK GP, WESSELING KH, SETTELS JJM, VAN VOLLENHOVEN E, WEEDA HWH, De WIT B, ARNTZENIUS AC: Evaluation of the Penaz servo-plethysmo-manometer for the continuous, noninvasive measurement of finger blood pressure. Basic Res Cardiol 79: 598-609, 1984.

NOVÁKOVÁ Z, HONZÍKOVÁ N, FIŠER B: Does baroreflex sensitivity play a role in the age - associated increase of blood pressure and prolongation of pulse interval in adolescents? Physiol Res 46: 3P, 1997.

NOVÁKOVÁ Z, HONZÍKOVÁ N, FIŠER B: Baroreflex sensitivity in children. Physiol Res 47: 2P, 1998.

NOVAKOVA Z, BALCARKOVA P, HONZIKOVA N, FISER B, ZAVODNA E, HRSTKOVA H, KRONTORADOVA K, STASTNA J: Arterial blood pressure and baroreflex sensitivity 1-18 years after completing anthracycline therapy. Neoplasma 54: 162-167, 2007. 
NOVÁKOVÁ Z, ŠŤASTNÁ J, HONZÍKOVÁ K, HRSTKOVÁ H, HONZÍKOVÁ N, ZÁVODNÁ E, FIŠER B, HONZÍK P: Anthracycline therapy and 24-hour blood pressure profile in long-term survivors of childhood cancer. Physiol Res 59: S97-S102, 2010.

PEŇÁZ J: Czechoslovak patent No. 133205, 1969.

PEŇÁZ J, ROUKENS J, v.d. WAAL HJ: Spectral analysis of some spontaneous rhythms in the circulation. Biokybernetik 1, H DRISCHEL, N TIEDT (eds), Leipzig, 1968, pp 233-236.

PEŇÁZ J, HONZÍKOVÁ N, FIŠER B: Spectral analysis of resting variability of some circulatory parameters in man. Physiol Bohemoslov 27: 349-357, 1978.

PEŇÁZ J, HONZÍKOVÁ N, JURÁK P: Vibration plethysmography: a method for studying the visco-elastic properties of finger arteries. Med Biol Eng Comput 35: 633-637, 1997.

PERSSON PB, DIRIENZO M, CASTIGLIONI P, CERUTTI C, PAGANI M, HONZIKOVA N, AKSELROD S, PARATI G: Time versus frequency domain techniques for assessing baroreflex sensitivity. $J$ Hypertens 19: 1699-1705, 2001.

RAHMOUNI K, CORREIA MLG, HAYNES WG, MARK AL: Obesity-associated hypertension: new insights into mechanisms. Hypertension 45: 9-14, 2005.

ROBE HJW, MULDER LJM, RUDEL H, LANGEWITZ WA, VELDMAN JBP, MULDER G: Assessment of baroreceptor reflex sensitivity by means of spectral analysis. Hypertension 10: 538-543, 1987.

SCHWARTZ PJ, VANOLI E, STRAMBA-BADIALE M, DE FERRARI GM, BILLMAN GE, FOREMAN RD: Autonomic mechanisms and sudden death: new insights from the analysis of baroreceptors reflexes in conscious dogs with and without a myocardial infarction. Circulation 78: 969-979, 1988.

SMYTH HS, SLEIGHT P, PICKERING GW: Reflex regulation of blood pressure during sleep in man: a quantitative method of assessing baroreflex sensitivity. Circ Res 24: 109-121, 1969.

SOROF JM: Prevalence and consequence of systolic hypertension in children. AJH 15: 57S-60S, 2002.

SWENNE CA: Baroreflex sensitivity: mechanisms and measurement. Netherlands Heart J 21: 58-60, 2013.

TANK J, JORDAN J, DIEDRICH A, STOFFELS M, FRANKE G, FAULHABER HD, LUFT FC, BUSJAHN A: Genetic influences on baroreflex function in normal twins. Hypertension 37: 907-910, 2001.

WEISE F, FIŠER B, HONZÍKOVÁ N: Cardiac baroreflex function during static muscular contraction assessed by finger arterial pressure and pulse interval spectral analysis. Homeostasis 36: 170-176, 1995.

WESSELING KH, DE WIT B, SETTELS JJ, KLAWER WH: On the indirect registration of finger blood pressure after Penaz. Funct Biol Med 1: 245-250, 1982.

ZANCHETTI A, BOND MG, HENNIG M, NEISS A, MANCIA G, PALU CD, HANSSON L, MAGNANI B, RAHN KH, REID J, RODICIO J, SAFAR M, ECKES L, RAVINETTO R: Risk factors associated with alterations in carotid intima-media thickness in hypertension: baseline data from the European Lacidipine Study on Atherosclerosis. J Hypertens 16: 949-961, 1998.

ZAVODNA E, HONZIKOVA N, HRSTKOVA H, NOVAKOVA Z, MOUDR J, JIRA M, FISER B: Can we detect the development of baroreflex sensitivity in humans between 11 and 20 years of age? Can J Physiol Pharmacol 84: 1275-1283, 2006. 